\title{
Native Weedy Pests of the Deep South
}

\author{
S. Christopher Marble ${ }^{1}$ \\ Department of Environmental Horticulture, University of Florida, Mid-Florida Research and Education Center, \\ 2725 South Binion Road, Apopka, FL 32703
}

Additional index words. invasive plants, nursery crops, landscapes, environmental horticulture

\begin{abstract}
By definition, an invasive plant is a non-native or alien species whose introduction causes or may cause economical or environmental harm. Due to well-documented and widespread devastating impacts of invasive plants, all exotic or introduced plant species often are erroneously referred to as invasive or considered detrimental, whereas native plants may be promoted as beneficial. Although invasive plants have been the subject of a great deal of research and discussion, less attention has been placed on native plant species that can become economically important weedy pests under certain scenarios, such as in landscape plantings or agricultural production systems. The objective of this manuscript is to synthesize current literature available on native weedy plants in Florida and other Southern United States (including Alabama, Arkansas, Georgia, Louisiana, North Carolina, Mississippi, South Carolina, Tennessee, and Texas) and discuss how their biology paired with human activities, preferences, and available management practices cause these species to proliferate and be problematic. Focus is placed on nine important native weeds in residential and commercial landscape plantings, including spurges (Euphorbia spp.), woodsorrels (Oxalis spp.), saw palmetto [Serenoa repens (Bartram) Small], bracken fern [Pteridium aquilinum (L.) Kuhn], artillery weed (Pilea microphylla L.), Virginia creeper [Parthenocissus quinquefolia (L.) Planch], trumpet creeper [Campsis radicans (L.) Seem. Ex Bureau], eastern poison ivy [Toxicodendron radicans (L.) Kuntze], and pennyworts/dollarweed (Hydrocotyle spp.). Reasons these species become problematic, including fast growth and reproductive rates, lack of selective management options, and ability to thrive in the landscape environment, also are discussed.
\end{abstract}

An invasive species is defined as "an alien (non-native) species whose introduction does or is likely to cause economic or environmental harm or harm to human health" (USDA, 2018a). Invasive plants have been subject to significant research from environmental (Pimentel et al., 2005), economical (Lovell et al., 2006; Olson, 2006), and management points of view (Kettenring and Adams, 2011). About 25,000 alien plant species have been introduced into the United States. Pyšek (1995) defined an alien species as "one which reached the area as a consequence of man or his domestic animals." Although some are very profitable agricultural crops [e.g., Zea mays L. (corn), Triticum spp. (wheat), Oryza sativa L. (rice)], many cause significant environmental harm, resulting in losses of $\$ 35$ billion annually (Pimentel et al., 2005). Due to the overall damage associated with invasive plants, more attention has been placed on invasive (i.e., exotic or non-native) weeds and their impacts. Although invasive plant species result in significant losses, native plants also may cause management issues by spreading aggressively in natural or managed systems, such as commercial or residential landscapes managed for aesthetic appeal.

Terms such as "invasive" or "exotic" are sometimes used synonymously by the layperson, and there is disagreement within academia in defining an invasive species and the difference in invasive plants vs. weeds (Davis and Thompson, 2001; Perrins

\footnotetext{
This paper results from the workshop entitled "Strategies for mitigating invasiveness of native species," held 20 Sept. 2017 at the ASHS Conference, Kona, Hawaii, and sponsored by the Invasive Plants Professional Interest Group (INPR).

${ }^{1}$ Corresponding author. E-mail: marblesc@ufl.edu.
}

et al., 1992). Many authors generally refer to weeds as problematic plants in managed sites, such as agriculture, whereas "invasives" are non-native plants growing aggressively or expanding in nonmanaged areas (Ellstrand, 2009; Radosevich et al., 2007). Alternatively, Rejmánek (2000) defined invasive taxa as a subset of naturalized taxa that are non-native and form sustainable populations without direct human help but not necessarily spreading. The general public may consider all exotic or weed plants as invasive, regardless of their native status, making consistent terminology very important when discussing different categories of species to avoid confusion (Caplat and Coutts, 2011). There is considerable debate about defining an invasive (Colautti and MacIsaac, 2004) or native species (Kendle and Rose, 2000; Webb, 1985), as not all species can be clearly categorized. Discussing the complex issues that lead to these categorizations such as time, human interaction, or geopolitical boundaries are beyond the scope of this manuscript but have been summarized in Kendle and Rose (2000).

It is common for authors to report native status differently for many species. To establish a delineation between native or exotic plants, the U.S. Department of Agriculture (USDA)-National Resources Conservation Service database (USDA-NRCS, 2018) was used here to classify species as native or introduced. Of the 357 weeds listed in the USDA Weeds of the U.S. list (USDA, $2018 \mathrm{~b}), 173(48 \%)$ are categorized as native or likely native. However, native status often is defined by geopolitical boundaries (such as the contiguous 48 states) and may not indicate true native range, such as Spartina alterniflora Loisel. (smooth cordgrass), which is native to the southeastern United States but invasive in parts of California due to hybridization and other factors (Ayres et al., 2004). The objective of this manuscript is to provide a concise description of about nine native weed pests in the southeastern United States, with specific focus on species that cause management issues or losses in ornamental landscapes and provide reasons why these native species become problematic (Table 1).

\section{COMMONALITIES OF NATIVE AND INTRODUCED WEEDS}

Generally, a weed is a plant (native or non-native) that is not valued where it is growing (USDA, 2018b). Regardless of native status, traits of all weedy plants (Mack, 1996; Olson, 1999), most notably by Baker (1974) include 1) ability to germinate in different environments, 2) longevity of seed, 3 ) rapid growth, 4) continuous seed production, 5) self-compatibility, 6) ability to cross pollinate, 7) prolific seed production, 8) high plasticity, 9) short- and long-distance seed dispersal mechanisms, 10) vigorous vegetative reproduction for perennial species, 11) not easily pulled from the ground, and 12) having a special competitive advantage (e.g., allelochemicals). Several comprehensive quantitative analysis of various weed species lists have been conducted to identify plant traits that may lead to "weediness." Kuester et al. (2014) analyzed plants from the USDA plants database and the Weed Science Society of America (WSSA) composite list of weeds (Van Wychen, 2016) to test for significant differences between weeds and nonweeds using both native and introduced species by examining traits, such as herbicide resistance, environmental stress tolerance, growth and reproductive rates, life cycle, genome size, and introduction date. Of the 12 traits evaluated, four (annual life form, high growth rate, 
Table 1. List of common native plants that become weeds in southern landscapes in the United States.

\begin{tabular}{lll}
\hline Genus and species & Common name & \multicolumn{1}{c}{ Native range $^{z}$} \\
\hline Acer rubrum & Red maple & Eastern United States, FL west to TX, north to Canada \\
Campsis radicans & Trumpet creeper & Throughout most of contiguous United States \\
Conyza canadensis & Horseweed & Throughout the United States and Canada \\
Cyperus surinamensis & Surinam sedge & FL west to TX, north to NE \\
Euphorbia maculata & Spotted spurge & Throughout contiguous United States \\
Hydrocotyle umbellata & Pennywort/dollarweed & Throughout Southeastern United States, CA and OR also listed \\
Oxalis corniculata & Creeping woodsorrel & Throughout contiguous United States \\
Oxalis stricta & Yellow woodsorrel & Most of contiguous United States, CA, OR, NV, UT not included \\
Parietaria floridana & Florida pellitory & Southeastern United States, FL west to TX, north to NC \\
Parthenocissus quinquefolia & Virginia creeper & Eastern United States, FL west to TX, north to Canada \\
Paspalum setaceum & Thin paspalum & Throughout most of contiguous United States \\
Pilea microphylla & Artillery weed & FL and southern portions of AL, AR, GA, LA, MS, TX \\
Pteridium aquilinum & Bracken fern & Throughout contiguous United States \\
Richardia scabra & Rough mexican clover & Southeastern United States, FL west to TX, north to VA \\
Serenoa repens & Saw palmetto & FL, TX, southern portions of AL, GA, LA, MS, SC \\
Sida acuta & Common sida & FL north to AL, west to TX \\
Toxicodendron radicans & Eastern poison ivy & Throughout eastern United States, east of TX, north to Canada \\
\hline
\end{tabular}

${ }^{\mathrm{Z}}$ Native status and range derived from USDA Plants Database (USDA-NRCS, 2018).

$\mathrm{FL}=$ Florida; $\mathrm{TX}=$ Texas; $\mathrm{NE}=$ Northeast $\mathrm{CA}=$ California; $\mathrm{OR}=$ Oregon; $\mathrm{NV}=$ Nevada; $\mathrm{UT}=\mathrm{Utah} ; \mathrm{NC}=$ North Carolina; $\mathrm{AL}=\mathrm{Alabama} ; \mathrm{AR}=\mathrm{Arkansas}$; $\mathrm{GA}=$ Georgia; LA = Louisiana; MS = Mississippi; VA = Virginia; SC = South Carolina.

high fruit abundance, and high seedling vigor) were more likely to be associated with weedy plants compared with nonweedy plants regardless of introduction status, and these traits were more likely to occur among introduced weeds compared with native weeds. The authors also found that although introduced weeds were more likely to be salt tolerant, they were less likely to be shade and calcium carbonate tolerant, indicating that native and introduced weeds may have different stress adaptations. In addition, $73 \%$ of herbicideresistant species in the U.S. flora were introduced weeds, and these species were more likely to rapidly reproduce a high number offspring. Sutherland (2004) performed a similar analysis and found that although certain traits such as generalized pollination, short regeneration time, competitive growth, or protection from herbivory such as being armored (spines or thorns) distinguished weeds from nonweeds, these traits were common among both native and nonnative weeds. Plants frequently perform better and are less affected by herbivores in an introduced range (Bossdorf et al., 2005). It is often assumed that exotic weeds are more aggressive than native weeds. However, some authors have stated that traits commonly associated with invasive plants are shared with many successful and expanding native species (Thompson and Davis, 2011; Thompson et al., 1995). Research by Kuester et al. (2014) and Sutherland (2004) also show that the same traits make invasive and native weeds successful.

When native plants become weeds, it is often due to human-induced disturbances such as agriculture, construction, or recreation that creates vegetation gaps (Baker, 1962; Thompson et al., 1995). A classic example of a native species aggressively spreading throughout its native range due to human disturbance is Juniperus virginiana L. (eastern redcedar) and other Juniperus species that were once confined to specific areas due to frequent fires that occurred in the grasslands in the Midwestern United States before human settlement. However, fire suppression by people, livestock overgrazing prairie grasses that previously outcompeted eastern redcedar, and other factors have led to this species becoming a troublesome weed in Oklahoma and other states (Ansley and Rasmussen, 2005).

Most research of plant invasions has focused on very large ecological scales at a national or regional level (Lonsdale, 1999). In these nonmanaged areas, genetic traits would likely be the primary means by which one species could outcompete another, and eventually become established/naturalized, and then possibly invasive. In managed landscapes, weedy traits common to both introduced and native weeds (Kuester et al., 2014; Sutherland, 2004) would still likely be required. However, some traits may not be as critical due to very high levels of routine and continual human activity that may provide additional opportunities for weeds to become aggressive or outcompete landscape plants due to inputs associated with plants grown for aesthetic purposes (e.g., irrigation, fertilization, insecticides and fungicides, etc.).

Another important distinction is the threshold in which these common or troublesome species are considered a nuisance or problematic. In natural or nonmanaged sites, plant species are of specific concern when they begin to alter native plant communities and ecological processes (Villa et al., 2011). Weeds, whether native or introduced, require action in food crops or other agricultural production systems when populations reach levels where yield is negatively impacted (Cousens, 1985). In landscapes managed for aesthetic purposes, pest thresholds can be extremely lowbased, depending on personal preferences and expectations (Raupp et al., 1988). Even when weed populations do not reach levels that affect landscape plants negatively, they may still be considered a nuisance due to their appearance in a highly manicured landscape.

\section{NATIVE INVADERS OF LANDSCAPES}

Many of the most common classical landscape weeds are native, such as Hydrocotyle spp. (pennyworts), some species of Digitaria (crabgrasses), specifically D. ciliaris (southern crabgrass), Gamochaeta purpurea (L.), Cabrera (purple cudweed), and several Oxalis spp. (woodsorrel) (Neal et al., 2017). In the 2015 WSSA survey of most common and troublesome weeds in landscapes (Van Wychen, 2016) (including survey results from ornamentals not classified as in a production system), $\approx 50 \%$ are classified by the USDA Plants database as native. Of the southern states that participated in the survey (Arkansas, Florida, Mississippi, North Carolina, Texas, and Virginia) the most frequently listed native species were Euphorbia spp. (syn. Chamaesyce) (spurges) (Van Wychen, 2016), whereas the most frequently introduced weed listed was $C y n$ odon dactylon (L.) Pers. (bermudagrass). Of the 30 plant species, 15 were introduced and 12 were native. Three species could be considered either native or introduced as some survey participants listed genera [e.g., Cardamine, which has introduced $(C$. hirsuta) and native ( $C$. pennsylvanica) species] when several species may be considered common or troublesome (Table 2).

In the southern United States, some of these native weeds can be especially problematic. Certain native species become weedy pests due to high seed production, fast growth rate, or ability to tolerate a wide range of environmental conditions, but management practices also play a role (Sutherland, 2004). If any unwanted plant can be considered a weed, any plant species could be considered a weed depending on the situation. However, for a species to receive attention (e.g., research to develop management guidelines, inclusion in identification guides, bulletins, and other resources, etc.), it typically must cause considerable management issues (aesthetic or otherwise) on a local, regional, or national level. By reviewing common 
Table 2. Native weeds ${ }^{\mathrm{z}}$ listed as common or troublesome in landscapes and ornamentals in the 2015 Weed Science Society of America weed survey. ${ }^{y}$

\begin{tabular}{lllc}
\hline & & \multicolumn{2}{c}{ States citing as common/troublesome } \\
\cline { 3 - 4 } Genera and species & \multicolumn{1}{c}{ Common } & Troublesome \\
\hline Cardamine spp. & Bittercress species & & FL \\
$\begin{array}{l}\text { Cyperus compressus } \\
\text { Eclipta prostrata }\end{array}$ & Annual sedge & Eclipta & MS \\
Euphorbia humistrata & Prostrate spurge & AR, MS, TX & FL \\
Euphorbia maculata & Spotted spurge & VA & MS \\
Euphorbia spp. & Spurge species & FL, NC & FL \\
Ipomoea spp. & Morningglory species & & NC \\
Oxalis corniculata & Creeping woodsorrel & VA & \\
Oxalis spp. & Woodsorrel species & FL & \\
Oxalis stricta & Yellow woodsorrel & FL, AR, MS & \\
Richardia spp. & Mexican clover species & FL & \\
Rubus trivialis & Southern dewberry & & TX \\
Sibara virginica & Virginia winged rockcress & MS & MS \\
Stachys floridana & Florida betony & & NC, TX \\
Toxicodendron radicans & Eastern poison ivy & &
\end{tabular}

${ }^{\mathrm{z}}$ Native status was based on USDA Plants Database (USDA-NRCS, 2018).

${ }^{\mathrm{y}}$ Responses used included those from southern U.S. states (AR, FL, MS, NC, TX, and VA) and included common or troublesome weeds in landscapes or in ornamentals not specified as being production ornamentals (i.e., in container or field production). Full survey results are available in Van Wychen (2016). ${ }^{\mathrm{x}}$ Survey respondents may have included only genera when multiple species from that genera are common or troublesome in landscapes. Those genera may include both native and introduced species.

$\mathrm{FL}=$ Florida MS = Mississippi; $\mathrm{AR}=$ Arkansas; $\mathrm{TX}=$ Texas; $\mathrm{VA}=$ Virginia $; \mathrm{NC}=$ North Carolina.

landscape weeds that are included in management or identification guides, it could be deduced that native weeds become problematic most commonly due to 1) fast growth and reproductive rates, 2) lack of effective or selective management options, or 3) ability to thrive in the landscape environment, especially when where proper cultural practices are not followed.

\section{NUISANCE NATIVES DUE TO FAST GROWTH AND REPRODUCTION}

Many weed species have the ability to reproduce and spread quickly (Kuester et al., 2014). The genera Oxalis (woodsorrel) and Euphorbia (spurge) contain several native species routinely identified as problematic in landscapes.

Many spurge species are widespread throughout the United States (Dunn, 1979). Spurges are well controlled by many pre- and postemergence herbicides labeled for use in landscapes (Neal et al., 2017); however, these species, particularly E. maculata (spotted spurge), have management issues due to a fast growth rate and high seed production (Ehrenfeld, 1976). A single plant may produce several thousand seeds (Molinar, 2009; Suzuki and Ohnishi, 2006). Early studies by Stevens (1932) showed seed production from common Euphorbia species such as E. nutans and $E$. humistrata ranged from 1720 to more than 14,000 per plant. In addition to significant seed development, vegetative and reproductive growth occur simultaneously in spotted spurge resulting in increased reproductive outputs (Suzuki and Ohnishi, 2006). Spotted spurge seed also has no dormancy requirement and can produce multiple generations per year (Neal and Derr, 2005; Suzuki and Ohnishi, 2006). Much research has been conducted to determine effective control methods for spurge (Altland et al.,
2002; Marble et al., 2009; Norcini and Aldrich, 1992; Stamps and Neal, 1990), but spurge continues to be one of the most common landscape weeds (Neal and Derr, 2005: Neal et al., 2017).

Despite susceptibility to most preemergence herbicides, several Oxalis spp. also are problematic weeds in landscapes and in the southern United States (Neal et al., 2017). The most common species encountered in southern landscapes is $O$. stricta or O. corniculata. Both species are perennial and become troublesome because of their ability to spread via seeds and vegetatively through rhizomes and stolons (Marshall, 1987; Neal and Derr, 2005). Stevens (1932) reported that $O$. stricta produces $\approx 570$ seeds per plant, but because of its perennial nature seed production could occur at almost any time of the year depending on the environment (Marshall, 1987). Both species also produce seed capsules that explosively dehisce on maturation, spreading seeds up to $2 \mathrm{~m}$ away from the mother plant (Van Der Pijl, 1969). Seeds of $O$. stricta and $O$. corniculata have no dormancy requirement (Neal and Derr, 2005) and can germinate over a broad range of temperatures (Holt, 1987). In studies by Holt (1987), fresh seeds of $O$. corniculata showed up to $90 \%$ germination.

Despite effective control by numerous herbicides, Euphorbia and Oxalis species are management challenges in landscapes because of their ability to produce copious amounts of highly viable seeds, ability to grow in a diverse range of conditions, and in the case of oxalis, ability to spread also spread vegetatively. Although cultural practices such as mulching also have been shown to provide effective control of both spurge and woodsorrel (Cochran et al., 2009; Wilen et al., 1999), mulch will decompose over time and will not provide long-term control without supplemental handweeding or use of herbicides (Marble et al., 2017). Spurge and oxalis are by no means the only two common native weed species that pose challenges due to rapid growth and reproductive rates, although they are very prevalent. Other common weed species that thrive in landscapes for these reasons include Acer rubrum L. (red maple), Parietaria floridana Nutt. (florida pellitory), and Richardia scabra L. (rough mexican clover), among others.

\section{NATIVES LACKING EFFECTIVE OR SELECTIVE MANAGEMENT OPTIONS}

Many native weeds are troublesome because of the lack of effective management options, such as Serenoa repens (Bartram) Small (saw palmetto) in Florida. Saw palmetto can grow up to 2.5 to $3.5 \mathrm{~m}$ tall and has a clumping growth habit that requires ample space not available in smaller landscapes. As the result of a deep root system, it is difficult to remove or transplant. Often the plants can become weedy in pastures, reducing forage yield, or can prevent access to power poles or other utilities. Although it is very slowgrowing, saw palmetto is very difficult to control. Some herbicides are effective (Fast et al., 2015), but most products found to be effective are not labeled for use in residential or commercial landscapes (Fast et al., 2015; Shiver et al., 1991).

Pteridium aquilinum (L.) Kuhn (bracken fern) is a species with several varieties native to North America and distributed all over the world (Page, 1976). In areas that are disturbed due to deforestation or agriculture and in landscapes, the species has a tendency to spread out of control and produce monocultures that prevent regeneration of other plants. Schneider (2006) reported that over the span of 15 years, areas occupied by bracken fern monocultures increased 4-fold in the Calakmul region in Mexico. In addition to aggressive growth, bracken fern are poisonous and a concern for grazing livestock (Knight and Walter, 2001). Multiple herbicides and other control measures have been evaluated on bracken fern in many parts of the world (Lawton, 1988; Milligan et al., 2016; Pakeman et al., 2002; Stewart et al., 2008). Bracken fern is difficult to control with herbicides because few chemicals, such as glyphosate, are translocated in large enough percentages to affect the rhizome (Gaskin and Kirkwood, 2017). Herbicides including 2,4-D, triclopyr, metsulfuron, and chlorsulfuron often are recommended for bracken fern control in pastures (Sellers et al., 2017), but these herbicides would not be suitable in most landscape situations.

Glyphosate is the top-selling pesticide worldwide (EPA, 2017) and is readily available to homeowners at retail outlets. Many homeowners do their own pest control, and glyphosate may be the only herbicide available for them to purchase in affordable quantities or without a pesticide license. Pilea microphylla L. (artillery weed) is 
a common weed in Florida and in many other southeastern states that is poorly controlled with glyphosate. Once widely planted as an ornamental groundcover (Blessington and Collins, 1993), artillery weed spreads aggressively in landscape planting beds and in cracks in hardscapes. Saha et al. (2017) reported that glyphosate provides only suppression of mature artillery weed, with fresh weight reductions ranging from $\approx 30 \%$ to $50 \%$ in one experiment. Numerous preemergence herbicides provide effective control, and herbicides including flumioxazin and glufosinate provide effective postemergence control (Saha et al., 2017). Although many of these herbicides are available to homeowners, they are typically only available for purchase in very large quantities (e.g., 9.5-L bottles or $23-\mathrm{kg}$ bags), which increases the cost considerably for homeowners managing small areas. Glyphosate-resistant biotypes of weeds such as Conyza canadensis (L.) Conq. (horseweed) pose the same challenges.

Vining weeds in landscapes commonly are reported as problematic because of the lack of selective herbicide options, and many of these species grow very quickly among desirable ornamental plants. Parthenocissus quinquefolia (L.) Planch (virginia creeper) is a native vining plant that grows on ornamental plants or fences in landscapes and considered a weed. Although not as competitive as some invasive vines, virginia creeper has shown ability to reduce growth of native trees, reducing height of Liquidambar syraciflua (sweetgum) by more than $30 \%$ in a 2 year field study (Dillenburg et al., 1993). Several studies have examined response of virginia creeper to herbicides (Richardson et al., 2009; Tworkoski et al., 1988; Tworkoski and Young, 1990). Most of the herbicides evaluated (2,4-D, triclopyr, hexazinone, glyphosate) on virginia creeper are not labeled for use in landscapes or would cause significant nontarget damage.

Other native vining weeds commonly found in landscapes include Campsis radicans L. Seem. Ex Bureau (trumpet creeper) and Toxicodendron radicans (L.) Kuntze (eastern poison ivy). Trumpet creeper is a troublesome weed in cotton (Gossypium spp.) fields and forestry (Webster, 2001) and also can become a management issue in landscapes because it often is planted for ornamental purposes and quickly grows to unmanageable levels. Trumpet creeper roots extensively when the vine has soil contact, making handweeding difficult, as stem fragments left behind can form new shoots (Edwards and Oliver, 2004).

Poison ivy lacks vigorous growth characteristic of trumpet creeper or virginia creeper but is difficult to control selectively when growing on trees and causes severe dermatitis, making manual removal a health hazard (Gladman, 2006). Poison ivy has been listed as one of the most troublesome landscape weeds (Van Wychen, 2016), although many herbicides, including ready-to-use mixtures, available to homeowners, provide control (Wehtje and Gilliam, 2012).

\section{NATIVE WEEDS THAT THRIVE IN THE LANDSCAPE ENVIRONMENT}

Improper use of fertilizers, irrigation, mowing, and other practices can stress turfgrass species and allow certain weed species to proliferate. Homeowners may be unaware of proper cultural practices, although $70 \%$ to $80 \%$ may perform their own lawn/garden maintenance (Butterfield, 1999; Varlamoff et al., 2001). Studies have shown that many homeowners do not know how much water they are applying with irrigation systems (Bremer et al., 2012) and may excessively irrigate their lawns (Romero and Dukes, 2011), which can increase growth of many weed species. Hydrocotyle spp. (pennyworts, dollarweed) are native to the southeastern United States and commonly grow in ditches, sloughs, or in floating mats (Tobe et al., 1998). Although lawns are not typical of a wetland habitat, excessive irrigation can increase incidence and spread of some native wetland species such as pennywort. In a study by Busey and Johnston (2006) H. umbellata L. (dollarweed) increased in cover and biomass with increasing irrigation and fertilization in a Stenotaphrum secundatum (Walt.) Kuntze (st. augustine grass) lawn. In severely wilted lawns, St. Augustine showed stress, and the cover of other weeds increased, including native species surinam sedge (Cyperus surinamensis Rottb.), thin paspalum (Paspalum setaceum Michx.), and southern sida (Sida acuta Burm f.).

Invasive plants will presumably have a greater response to high nitrogen availability compared with natives. Rickey and Anderson (2004) showed that the invasive exotic grasses Phragmites australis Cav. Trin. Ex Steud. (common reed) benefited from additional nitrogen to a much greater degree than the native Spartina pectinata Bosc ex Link (prairie cordgrass) and, thus, would be able to outcompete prairie cordgrass in high nitrogen environments. However, Lowe et al. (2002) reported no difference in nitrogen response between two native plant species, including blue grama (Bouteloua gracilis H.B.K. Lag.) and western wheatgrass [Pascopyrum smithii (Rybd.) A. Love], and four exotic species, including cheatgrass (Bromus tectorum L.), leafy spurge (Euphorbia esula L.), canada thistle (Cirsium arvense L.), and russian knapweed (Centaurea repens L.). In a meta-analysis, Davidson et al. (2011) reported that invasive plants have greater phenotypic plasticity than co-occurring noninvasive plants, but this might not be related to performance or fitness. Daehler (2003) reviewed invasive and native plant comparison studies and found 79 studies showing there were no differences in growth rate, competitive ability, or fecundity between the invasive and native plant pairs and that the performance of the invaders depended on the growing conditions. In 55 comparisons that involved more than one growing condition, the native plant performed as well or better than the invasive plant. Although landscapes are vulnerable to many invasive or introduced weed species \{e.g., doveweed [Murdannia nudiflora (L.) Brenan] or hairy crabgrass [Digitaria sanguinalis (L.) Scop.]\}, native plants can become weedy in the artificial environment of a residential landscape.

\section{CONCLUSIONS}

Landscapes are vulnerable to weed infestations in many ways. Many non-native and native species (such as spurge or wood sorrel) are routinely reintroduced to landscapes via infested container-grown ornamentals. Almost any weed could become problematic in container nursery production due to high levels of fertilization and irrigation (Stewart et al., 2017). Weeds also may be introduced with mowers and other lawn equipment or wind. Once in the landscape, weeds may persist through high reproductive rates or the ability to tolerate landscape labeled herbicides and other treatment options. When desirable ornamentals or turf is present, chemical control options are more limited due to high potential for nontarget damage. If control options are lacking, inputs intended for the landscape, such as fertilizer, can cause these weeds to grow and spread further (Blackshaw et al., 2003). Problematic landscape weeds may not necessarily outcompete ornamentals for resources but can create aesthetic issues at even very low levels for some homeowners. A survey by Varlamoff et al., (2001) showed $76 \%$ of Georgia residents rated a weed-free lawn as important, and previous research showed weed coverage thresholds were $\approx 10 \%$ (Carpenter and Meyer, 1999).

Introduced invasive plants cost millions of dollars each year to manage, threaten biodiversity, and reduce property values. In contrast, native plants are promoted for the many benefits they provide, including their aesthetic value, providing food for wildlife, attracting and supporting pollinators, and are popular among homeowners (Helfand et al., 2006). Native plants also very commonly promoted for their low-maintenance characteristics. Native plants often are indeed low maintenance in terms of water or pesticide needs, as they are adapted to local environmental conditions. However, as outlined here, many native plants can become aggressive in anthropogenic environments and troublesome as the result of our own expectations or preferences. Many of the species outlined in this manuscript would not be planted for aesthetic purposes, but it is important to evaluate and document aggressive tendencies of native plants under different environmental conditions, rather than applying broad generalizations such as classifying all natives as "low maintenance." This is especially important when considering the confusion and many challenges that arise when basing native status on geopolitical boundaries. Future research should focus on identifying the role that different environmental conditions or various maintenance practices have in the unwanted spread of native species. 
Additional information in this area could help direct the selection of native plants for ornamental purposes. If a native species had a tendency to spread uncontrollably in a given situation, another native species or a noninvasive, non-native species could be chosen instead. Although many aggressive native species have been identified in this manuscript as being problematic in landscapes, these species serve critical ecological functions in their natural habitat. An additional area that deserves further investigation is how to use the aggressive growth and reproductive abilities of these native plants for environmental benefits. As detailed in $\mathrm{Li}$ et al. (2015), some of the more-aggressive native species could be used as management tools to outcompete invasive non-native plants in different environments ( $\mathrm{Li}$ et al., 2015). A common mantra of landscape design is to select the right plant for the right place. When selecting plants for a landscape, environmental benefits, aesthetic value, and long-term maintenance needs, including the potential for unwanted spread, should be considered regardless of native status.

\section{Literature Cited}

Altland, J.E., C.H. Gilliam, and J.W. Olive. 2002. Postemergence prostrate spurge (Chamaesyce prostrata) control in container-grown liriope. J. Environ. Hort. 20:41-46.

Ansley, R.J. and G.A. Rasmussen. 2005. Managing native invasive juniper species using fire. Weed Technol. 19:517-522.

Ayres, D.R., D.L. Smith, K. Zaremba, S. Klohr, and D.R. Strong. 2004. Spread of exotic cordgrasses and hybrids (Spartina sp.) in the tidal marshes of San Francisco Bay, California, USA. Biol. Invasions 6:221-231.

Baker, H.G. 1962. Weeds-native and introduced. J. Calif. Hort. Soc. 23:97-104.

Baker, H.G. 1974. The evolution of weeds. Annu. Rev. Ecol. Syst. 5:1-24.

Blackshaw, R.E., R.N. Brandt, H.H. Janzen, T. Entz, C.A. Grant, and D.A. Derksen. 2003. Differential response of weed species to added nitrogen. Weed Sci. 51:532-539.

Blessington, T.M. and P.C. Collins. 1993. Foliage plants: Prolonging quality: Postproduction care and handling. Ball Publishing, Batavia, IL.

Bossdorf, O., H. Auge, L. Lafuna, W.E. Rogers, E. Siemann, and D. Prati. 2005. Phenotypic and genetic differentiation between native and introduced plant populations. Oecologia 144:1-11.

Bremer, D.J., S.J. Keeley, A. Jager, J.D. Fry, and C. Lavis. 2012. In-ground irrigation systems affect lawn-watering behaviors of residential homeowners. HortTechnology 22:651-658.

Busey, P. and D.L. Johnston. 2006. Impact of cultural factors on weed populations in St. Augustinegrass turf. Weed Sci. 54:961-967.

Butterfield, B.W. 1999. National gardening survey 1998-1999. Natl. Gardening Assn., Burlington, VT.

Caplat, P. and S.R. Coutts. 2011. Integrating ecological knowledge, public perception, and urgency of action into invasive species management. Environ. Mgt. 48:878.

Carpenter, P.J. and M.H. Meyer. 1999. Edina goes green Part III: A survey of consumer lawn care knowledge and practices. HortTechnology 9:491-494.

Cochran, D.R., C.H. Gilliam, D.J. Eakes, G.R. Wehtje, P.R. Knight, and J. Olive. 2009. Mulch depth affects weed germination. J. Environ. Hort. 27:85-90.

Colautti, R.I. and H.J. MacIsaac. 2004. A neutral terminology to define 'invasive' species. Divers. Distrib. 10:135-141.

Cousens, R. 1985. A simple model relating yield loss to weed density. Ann. Appl. Biol. 107:239-252.

Daehler, C.C. 2003. Performance comparisons of co-occurring native and alien invasive plants: Implications for conservation and restoration. Ann. Rev. Ecol. Evol. Syst. 34:183-211.

Davidson, A.M., M. Jennions, and A.B. Nicotra 2011. Do invasive species show higher phenotypic plasticity than native species and, if so, is it adaptive? A meta-analysis. Ecol. Lett. 14: 419-431.

Davis, M. and K. Thompson. 2001. Invasion terminology: Should ecologists define their terms differently than others? No, not if we want to be of any help! Bull. Ecol. Soc. Amer. 82:206.

Dillenburg, L.R., D.F. Whigham, A.H. Teramura, and I.N. Forseth. 1993. Effects of below- and aboveground competition from the vines Lonicera japonica and Parthenocissus quinquefolia on the growth of tree hos Liquidambar styraciflua. Oecogia 93:48-54.

Dunn, P.H. 1979. The distribution of leafy spurge (Euphorbia esula) and other weedy Euphorbia spp. in the United States. Weed Sci. 27:509-516.

Edwards, J.T. and L.R. Oliver. 2004. Emergence and growth of trumpetcreeper (Campus radicans) as affected by rootstock size and planting depth. Weed Technol. 18:816-819.

Ehrenfeld, J. 1976. Biology of three species of euphorbia subgenus Chamaesyce (Euphorbiaceae). Amer. J. Bot. 63:406-413.

Ellstrand, N.C. 2009. Evolution of invasiveness in plants following hybridization. Biol. Invasions 11:1089-1091.

Environmental Protection Agency. 2017. Pesticides industry sales and usage: 2008-2012 market estimates. 23 Mar. 2018. < https://www. epa.gov/sites/production/files/2017-01/documents/ pesticides-industry-sales-usage-2016_0.pdf > .

Fast, B., J. Ferrel, and B. Sellers. 2015. Saw palmetto control: Individual plant and broadcast application. University of Florida EDIS no. SS-AGR-341. 29 June 2018. <http://edis.ifas. ufl.edu/ag351>.

Gaskin, R.E. and R.C. Kirkwood. 2017. The effect of certain nonionic surfactants on the uptake and translocation of herbicides in bracken (Pteridium aquilinium [L.] Kuhn), p. 120-131. In: N.P. Chow, C.A. Grant, A.M. Hinshalwood, and E. Simundsson (eds.). Adjuvants and agrochemicals. Vol. I. Mode of action and physiological activity. CRC Press: Boca Raton, FL.

Gladman, A.C. 2006. Toxicodendron dermatitis: Poison ivy, oak, and sumac. Wilderness Environ. Med. 17:120-128.

Helfand, G.E., J.S. Park, J.I. Nassauer, and S Kosek. 2006. The economics of native plants in residential landscape designs. Landsc. Urban Plan. 78:229-240.

Holt, J.S. 1987. Factors affecting germination in greenhouse-produced seeds of $O$. corniculata, a perennial weed. Amer. J. Bot. 7:429-436.

Kendle, A.D. and J.E. Rose. 2000. The aliens have landed! What are the justifications for 'native only' policies in landscape plantings? Landsc. Urban Plan. 47:19-31.

Kettenring, K.M. and C.R. Adams. 2011. Lessons learned from invasive plant control experiments: A systematic review and meta-analysis. J. Appl. Ecol. 48:970-979.

Knight, A.P. and R. Walter. 2001. A Guide to Plant Poisoning of Animals in North America. Teton New Media, Jackson, WY.
Kuester, A., J.K. Conner, T. Culley, and R.S. Baucom. 2014. How weeds emerge: A taxonomic and trait-based examination using United States data. New Phytol. 202:1055-1068.

Lawton, J.H. 1988. Biological control of bracken in Britain: Constraints and opportunities. Philos. Trans. R. Soc. Lond. B Biol. Sci. 318:335-355.

Li, W., J. Luo, X. Tian, W.S. Chow, Z. Sun, T. Zhang, S. Peng, and C. Peng. 2015. A new strategy for controlling invasive weeds: Selecting valuable native plants to defeat them. Sci. Rep. 11004.

Lonsdale, W.M. 1999. Global patters of plant invasions and the concept of invisibility. Ecology 80:1522-1536.

Lovell, S.J., S.F. Stone, and L. Fernandez. 2006. The economic impacts of aquatic invasive species: A review of the literature. Agr. Resour. Econ. Rev. 35:195-208.

Lowe, P.N., W.K. Lauenroth, and I.C. Burke. 2002. Effects of nitrogen availability on the growth of native grasses and exotic weeds. J. Range Mgt. 55:94-98.

Mack, R.N. 1996. Predicting the identity and fate of plant invaders: Emergent and emerging approaches. Biol. Conserv. 78:107-121.

Marble, S.C., A.K. Koeser, G. Hasing, D. McClean, and A. Chandler. 2017. Efficacy and estimated annual cost of common weed control methods in landscape planting beds. HortTechnology 27:199-211.

Marble, S.C., C.H. Gilliam, G.R. Wehtje, A.J. Van Hoogmoed, and C. Palmer. 2009. Early postemergence control of spotted spurge in container production. J. Environ. Hort. 29:29-34.

Marshall, G. 1987. A review of the biology and control of selected weed species in the genus Oxalis: O. stricta L., O. latifolia H.B.K. and $O$. pes-caprae L. Crop Prot. 6:355-364.

Milligan, G., E.S. Cox, J.G. Alday, V.M. Santana, H.A. McAllister, R.J. Pakeman, M.G. Le Duc, and R.H. Marrs. 2016. The effectiveness of old and new strategies for the long-term control of Pteridium aquilinum, an 8-year test. Weed Res. 56:247-257.

Molinar, P. 2009. Spotted spurge and other spurges. Pest Notes UC Coop. Ext. No. 7445. 24 June 2018. <http://ipm.ucanr.edu/PMG/PESTNOTES/ pn7445.html $>$.

Neal, J., J.C. Chong, and J. Williams-Woodward (eds.). 2017. Southeastern US pest control guide for nursery crops and landscape plantings. 25 Feb. 2018. <https://content.ces.ncsu. edu/southeastern-us-pest-control-guide-fornursery-crops-and-landscape-plantings $>$.

Neal, J.C. and J.F. Derr. 2005. Weeds of container nurseries in the United States. North Carolina Association of Nurserymen. Raleigh, NC.

Norcini, J.G. and J.H. Aldrich. 1992. Spotted spurge control and phytotoxicity to daylily from preemergence herbicides. J. Environ. Hort. 10:14-17.

Olson, B.E. 1999. Grazing and weeds, p. 85-96. In: R.L. Sheley and J.K. Petroff (eds.). Biology and management of noxious rangeland weeds. Oregon St. Univ. Press, Corvallis, OR.

Olson, L.J. 2006. The economics of terrestrial invasive species: A review of the literature. Agr. Resour. Econ. Rev. 35:178-194.

Page, C.N. 1976. The taxonomy and phytogeography of bracken: A review. Bot. J. Linn. Soc. 73:1-34.

Pakeman, R.J., R.H. Thwaites, M.G. Le Duc, and R.H. Marrs. 2002. The effects of cutting and herbicide treatment on Pteridium aquilinum encroachment. Appl. Veg. Sci. 5:203-212.

Perrins, J., M. Williamson, and A. Fitter. 1992. A survey of differing views of weed classification: 
Implications for regulation of introductions. Biol. Conserv. 60:47-56.

Pimentel, D., R. Zuniga, and D. Morrison. 2005. Update on the environmental and economic costs associated with alien-invasive species in the United States. Ecol. Econ. 52:273-288.

Pyšek, P. (1995). On the terminology used in plant invasion studies, p. 71-81. In: P. Pyšek, K. Prach, M. Rejmánek, and M. Wade (eds.). Plant Invasions - General Aspects and Specific Problems. SPB Academic Publishing, Amsterdam.

Radosevich, S.R., J.S. Holt, and C.M. Ghersa. 2007. Ecology of weeds and invasive plants: Relationship to agriculture and natural resource management. 3rd ed. Wiley Publishing, New York, NY

Raupp, M.J., J.A. Davidson, C.S. Koehler, C.S. Sadof, and K. Reichelderfer. 1988. Decisionmaking considerations for aesthetic damage caused by pests. Bull. Entomol. Soc. Amer. 34:27-32.

Rejmánek, M. 2000. Invasive plants: Approaches and predictions. Austral. Ecol. 25:497-506.

Richardson, R.J., M.W. Marshall, R.E. Uhlig, and B.H. Zandstra. 2009. Virginia creeper (Parthenocissus quinquefolia) and wild grape (Vitis spp.) control in Fraser fir. Weed Technol. 23:184-187.

Rickey, M.A. and R.C. Anderson. 2004. Effects of nitrogen addition on the invasive grass Phragmites australis and a native competitor Spartina pectinata. J. Appl. Ecol. 41:888-896.

Romero, C.C. and M.D. Dukes. 2011. Are landscapes over-irrigated in Southwest Florida? A spatial-temporal analysis of observed data. Irrig. Sci. 29:391-401.

Saha, D., S.C. Marble, C. Stewart, and A. Chandler. 2017. Preemergence and postemergence control of artilleryweed (Pilea microphylla) in container nurseries and landscapes. Weed Technol. 31:574-581.

Schneider, L.C. 2006. Invasive species and landuse: The effect of land management practices on bracken fern invasion in the region of Calakmul, Mexico. J. Lat. Amer. Geogr. 5:92-107.

Sellers, B., J. Ferrell, and T. Wilson. 2017. Bracken fern control in pastures. Univ. Fl. EDIS pub.
No. SS-AGR-357. 7 Mar. 2018. $<\mathrm{http} / /$ :edis. ifas.ufl.edu/ag366>.

Shiver, B.D., S.A. Knowe, M.B. Edwards, and W.N. Kline. 1991. Comparison of herbicide treatments for controlling common coastal flood plain flatwoods species. South. J. Appl. For. 15:187-193.

Stamps, R.H. and C.A. Neal. 1990. Evaluation of dinitroaniline herbicides for weed control in container landscape plant production. J. Environ. Hort. 8:52-57.

Stevens, O.A. 1932. The number and weight of seeds produced by weeds. Amer. J. Bot. 19:784-794.

Stewart, C.J., S.C. Marble, B.J. Pearson, and P.C. Wilson. 2017. Impact of container nursery production practices on weed growth and herbicide performance. HortScience 52:15931600.

Stewart, G., E. Cox, M. Le Duc, R. Pakeman, A. Pullin, and R. Marrs. 2008. Control of Pteridium aquilinum: Meta-analysis of a multi-site study in the UK. Ann. Bot. 101:957-970.

Sutherland, S. 2004. What makes a weed a weed: Life history traits of native and exotic plants in the USA. Oecologia 141:24-39.

Suzuki, N. and Y. Ohnishi. 2006. Significance of the simultaneous growth of vegetative and reproductive organs in the prostrate annual Chamaesyce maculata (L.) Small (Euphorbiaceae). Ecol. Res. 21:91-99.

Thompson, K. and M.A. Davis. 2011. Why research on traits of invasive plants tells us very little. Trends Ecol. Evol. 26:155-156.

Thompson, K., J.G. Hodgson, and T.C.G. Rich. 1995. Native and alien invasive plants: More of the same? Ecography 18:390-402.

Tobe, J.D., K.C. Burks, R.W. Cantrell, M.A. Garland, M.E. Sweeley, D.W. Hall, P. Wallace, G. Anglin, G. Nelson, J.R. Cooper, D. Bickner, K. Gilbert, N. Aymond, K. Greenwood, and N. Raymond. 1998. Florida wetland plants: An identification guide. Florida Department of Environmental Protection, Tallahassee, FL.

Tworkoski, T.J. and R.S. Young. 1990. Rate and time of triclopyr application to control Virginia creeper in a peach orchard. HortScience 25 : 443-445.
Tworkoski, T.J., R.S. Young, and J.P. Sterrett. 1988. Control of Virginia creeper (Parthenocissus quinquefolia): Effects of carrier volume on toxicity and distribution of triclopyr. Weed Technol. 2:31-35.

United States Department of Agriculture (USDA). 2018a. National Invasive Species Information Center, National Agricultural Library. 13 Mar. 2018. <https://www.invasivespeciesinfo.gov/ index.shtml $>$.

United States Department of Agriculture (USDA). 2018b. Weeds of the United States and Canada. 4 Feb. 2018. <https://plants.usda.gov/java/ invasiveOne?pubID $=$ SWSS $>$.

United States Department of Agriculture Natural Resources Conservation Service (USDA-NRCS). 2018. The PLANTS database. 26 Mar. 2018. $<$ http://plants.usda.gov>.

Van Der Pijl, L. 1969. Principles of dispersal in higher plants. Springer-Verlag. Berlin, Germany.

Van Wychen, L. 2016. 2015 Baseline survey of the most common and troublesome weeds in the United States and Canada. Weed Science Society of America. 23 Feb. 2018. <http://wssa. net/wp-content/uploads/2015-Weed-Survey_ Baseline.xlsx $>$.

Varlamoff, S., W.J. Florkowski, J.L. Jordan, J. Latimer, and K. Braman. 2001. Georgia homeowner survey of landscape management practices. HortTechnology 11:326-331.

Villa, M., J.L. Espinar, M. Hejda, P.E. Hulme, V. Jarosik, J.L. Maron, J. Pergl, U. Sshaffner, Y. Sun, and P. Pysek. 2011. Ecological impacts of invasive alien plants: A meta-analysis of their effects on species, communities and ecosystems. Ecol. Lett. 14:702-708.

Webb, D.A. 1985. What are the criteria for presuming native species? Watsonia 15:231-236.

Webster, T.M. 2001. Weed survey-southern states, broadleaf crops subsection. Proc. South. Weed. Sci. Soc. 54:244-259.

Wehtje, G. and C.H. Gilliam. 2012. Costeffectiveness of glyphosate, 2,4-D, and triclopyr, alone and in select mixtures for poison ivy control. Weed Technol. 26:469-473.

Wilen, C.A., U.K. Schuch, and C.L. Elmore. 1999. Mulches and subirrigation control weeds in container production. J. Environ. Hort. 17:174-180. 